\title{
Unpopular Protest: Mass Mobilization and Attitudes to Democracy in Post-Mubarak Egypt
}

\author{
Neil Ketchley, University of Oslo \\ Thoraya El-Rayyes, London School of Economics and Political Science
}

\begin{abstract}
Political science has long debated the significance of protest during a democratic transition, but attention has been largely confined to its impact on elite support for democracy. Contributing to scholarship on the attitudinal consequences of mobilization, we examine how protest shaped popular perceptions of democracy during the post-Mubarak transition in Egypt. We do this by matching wave 2 of the Arab Barometer survey with georeferenced protest events reported in Arabiclanguage newspapers. Our results show that Egyptians came to hold less favorable attitudes to democracy following sustained protest in their district. We find that this relationship was principally driven by longer-lasting, static street protests that targeted public space. Qualitative case details illustrate how such tactics could disrupt everyday life and affect livelihoods. These findings highlight one way in which popular support for democracy can be eroded during a transition.
\end{abstract}

$\mathrm{T}$ he relationship between street protest and democratization is a vexed one. A body of research finds that mass mobilization can fatally weaken an authoritarian regime and bring about a democratic breakthrough (e.g., Bunce and Wolchik 2011; Kadivar 2018; Thompson 2003). By comparison, the role of protest during a subsequent democratic transition is much less clear-cut. ${ }^{1}$ Transitologists have argued that protestors should demobilize after an authoritarian has been ousted or risk alienating societal elites and soft-liners from the former regime (e.g., Linz and Stepan 1996; O'Donnell and Schmitter 1986; Przeworski 1991). A second literature insists that continued protest can deepen the transitional process by forcing elites to make concessions, while checking authoritarian backsliding (e.g., Bermeo 1997; Collier 1999; Kadivar and Ketchley 2018). Against this backdrop, it is surprising that little attention has been paid to how protest shapes popular attitudes to democracy over a transition. Political and economic dynamics during this critical period can affect how individuals perceive democracy (Evans and White- field 1995; Mattes and Branton 2007). And as Meirowitz and Tucker (2013) theorize, citizens can lose enthusiasm for democracy if they are negatively affected by new forms of democratic politics.

In this article, we examine how an unprecedented wave of protest shaped popular attitudes to democracy during the post-Mubarak transition in Egypt. Here we contribute to a new body of scholarship that seeks to understand protest not simply as an outcome to be explained but as a phenomenon that is itself generative of political attitudes (see, e.g., Branton et al. 2015; Mazumder 2018; Wallace, Zepeda-Millán, and Jones-Correa 2014). To conduct our analysis, we combine an in-person survey fielded in Egypt after the ousting of Husni Mubarak in 2011 with a georeferenced catalog of protest events reported in Arabic-language publications. The period between Mubarak's departure and the deployment of the survey saw workers, activists, and local residents stage over 2,000 protests across the country. For identification, we use an instrumental variable that exploits respondents' spatial

Neil Ketchley (neil.ketchley@stv.uio.no) is an associate professor of political science in the Department of Political Science, University of Oslo, Oslo, Norway 0851. Thoraya El-Rayyes (t.el-rayyes@lse.ac.uk) is a PhD candidate in political science in the Department of Government at the London School of Economics and Political Science, London WC2A 2AE.

The analysis draws on a nonpublic version of wave 2 of the Arab Barometer for Egypt, which can be requested from https://www.arabbarometer.org /contact/. Data and supporting materials necessary to reproduce the numerical results in the article are available in the JOP Dataverse (https://dataverse.harvard.edu /dataverse/jop). An online appendix with supplementary material is available at https://doi.org/10.1086/709298.

1. By democratic transition, we mean a democratization process that begins with the ousting of an authoritarian and ends with the consolidation of democracy (see Linz and Stepan 1996).

The Journal of Politics, volume 83, number 1. Published online January 5, 2021. https://doi.org/10.1086/709298

(C) 2021 by the Southern Political Science Association. All rights reserved. 0022-3816/2021/8301-0020\$10.00 
relationship to protest ecologies that emerged during the January 25 Revolution.

Our results suggest that Egyptians came to hold more negative attitudes to democracy following sustained protest in their district. In such areas, survey respondents were more likely to associate democracy with economic and moral threat, indecisive government, and instability. Disaggregating our measure of mobilization, we find that this relationship was primarily due to protestors using longer-lasting, street-level tactics that disrupted public space. Qualitative case details attest to the fallout of this type of protest and suggest that popular disquiet was related to the negative impact of disruptive protest on livelihoods and the routine practices of everyday life.

In making sense of these findings, we argue that the high levels of mobilization witnessed in the post-Mubarak transition caused some Egyptians to update their view of how democracy functions in practice. Transitional periods are often low-information settings characterized by a high level of uncertainty in which citizens are forming opinions about the emerging nature of a democratic regime (Mattes and Bratton 2007; Meirowitz and Tucker 2013). In such settings, direct experience can serve as a key source of, or shortcut for, information (Mattes and Bratton 2007). Crucially, protest elicits concessions by inflicting a cost on authorities, and this can have knock-on effects for broader publics: roads and offices are blocked, businesses are closed, and public services are rendered unavailable. During the post-Mubarak transition, experience of sustained and disruptive street protest appears to have led some Egyptians to associate democracy with the negative externalities of mobilization.

\section{ATTITUDINAL CONSEQUENCES OF PROTEST}

After several decades focusing on the drivers of mass mobilization, research on collective protest increasingly focuses on its consequences (for a review, see Amenta et al. 2010). A new strand of this literature focuses specifically on how protest shapes political attitudes. In the context of the 2006 Latino immigrant rallies in the United States, Wallace et al. (2014) investigate the differential effects of proximity to small- versus large-scale protests on feelings of political efficacy. Analyzing the same episode of protest, Branton et al. (2015) exploit a quasi experiment to show that the effect of protest on policy preferences depends on the local intensity of streetlevel activism. Looking at the effects of historic mobilization, Andrews, Beyerlein, and Farnum (2015) find that white Southerners held more positive attitudes to antisegregation protests in areas that saw a sit-in during the civil rights movement. Similarly, Mazumder (2018) argues that counties became more politically liberal as a consequence of hosting a civil rights protest. Tertytchnaya and Lankina (2020) find that Russians living in regions with more antiregime protests held more negative attitudes toward the opposition if they received their news from state-controlled media outlets.

While all of these analyses suggest that the experience of protest can influence political attitudes, the generalizability of their findings remains limited in several ways. With the notable exception of the Tertytchnaya and Lankina study, this genre of research remains overwhelmingly focused on protest in the United States, and so it remains unclear how these insights travel to contexts that are not mature democracies. Moreover, the literature has tended to study cases of low-level, episodic mobilization. This is convenient for quasiexperimental research designs, which exploit serendipitous contention that occurs while a survey is in the field. However, it is less clear how political attitudes will be patterned by more sustained mobilization or protest that occurs in politically unstable or recently authoritarian contexts. Our study expands research on the attitudinal consequences of protest to include the case of a transitional regime experiencing intense and protracted protest following a democratic breakthrough.

\section{PROTEST, ATTITUDES, AND DEMOCRATIZATION}

Early research on third-wave democratization conceived of the process of democratic transition as one of bargaining between regime and moderate opposition elites over authoritarian exit. For democratization to succeed, transitologists argued, moderate opponents must enter into pacts with the business class, members of the security forces, and former regime soft-liners and guarantee that their interests and prerogatives will not be significantly diminished by new forms of civilian democratic authority (e.g., O'Donnell and Schmitter 1986; Przeworski 1991). To avoid alienating those actors and empowering old regime hard-liners, protest movements agitating for social justice and other forms of redress must demobilize and shift their attention to participating in elections (Linz and Stepan 1996, 10).

If transitologists portray popular protest as either epiphenomenal or orthogonal to the successful unfolding of a democratic transition, another body of scholarship highlights the productive power of street protest in sustaining democratization after the ousting of an authoritarian. In her seminal study of third-wave democratization, Bermeo (1997) argued that episodes of protest not only failed to scotch democratic transitions but actually enhanced the bargaining position of moderate opposition figures in their negotiations with regime hard-liners. Similarly, Ekiert and Kubik (1999) showed that protest in Poland provided a key outlet for popular grievances, while also binding former communist hard-liners to the 
transition. In a recent study, Kadivar and Ketchley (2018) examined all 82 democratic transitions that occurred between 1980 and 2010 and found that unruly mobilization often forced old regime actors to make key concessions, thus deepening the democratization process.

While these literatures diverge on the effects of protest during a democratic transition, they agree on the underlying mechanism: protest inflicts a cost on elites by disrupting economic, political, and social life. Elites then use this information to forecast how they will fare under a democracy. This leaves unexplained how the costs of protest pattern popular attitudes following a democratic breakthrough. A body of research suggests that nonelites also update their assessments of democracy during transitional periods, especially when the new modalities of politics significantly diverge from what came before (e.g., Evans and Whitefield 1995; Mattes and Bratton 2007; Meirowitz and Tucker 2013). It is for this reason that a democratic transition has been characterized as a learning process in which citizens adjust their assessments of democracy depending on how it is perceived to perform in practice. Importantly, in transitional settings, where much is in flux, signals from government officials and politicians tend to be inconsistent or unreliable. In consequence, as Mattes and Bratton (2007) show, direct experiences of the perceived functioning of democracy can be particularly formative.

Following Tertytchnaya and Lankina (2020), who conceptualize protest as a source of information, we suspect that the level of local mobilization during a transition may feature as a heuristic that individuals draw on to form opinions about the quality of governance in a future democratic regime. One observed implication from the transitology literature is that personal dissatisfaction arising from protest could translate into more negative assessments of democracy as a whole. Our expectation about the direction of this relationship is also informed by the case literature from the $2011 \mathrm{Arab}$ Spring. Bayat $(2017,211)$ posits that where the daily disruption of intense and protracted protest was combined with economic strain, a general mood emerged "in favour of order, stability and a desire for a resolute, even repressive leader." Tripp $(2013,210)$ theorized that mass mobilization was likely to be subject to "dramatic decay." Sustained protest, while initially generative of excitement and anticipation, would quickly be greeted with cynicism and disenchantment with political change. So too, Arslanalp and Pearlman $(2017,317)$ cautioned that sustained mobilization could provoke fear and uncertainty, and so lead to popular support for old regime actors to intervene into the transitional process under the guise of restoring stability. Mazaheri and Monroe (2018) provide the only systematic evidence for this dynamic. Using survey data, they show that Arab business owners held less favorable views of democracy in countries that saw protest post-2011.

If the knock-on effect of local mobilization shapes individuals' perceptions of how democracy performs in practice, we hypothesize that any link between protest and political attitudes will geographically cluster in areas that see more mobilization. A one-off protest is not likely to have much of an effect; however, daily protest in the same place over a prolonged period may. In what follows, we test this claim by exploring the attitudinal consequences of mobilization during the post-Mubarak transition in Egypt in 2011.

\section{PROTEST AND DEMOCRATIC TRANSITION IN EGYPT}

The years leading up to Egypt's democratic breakthrough saw ongoing protests by a range of actors. However, the scale of mobilization witnessed in Egypt following the fall of Husni Mubarak in February 2011 represented a quantitative shift in Egyptians' experience of street-level activism. To contextualize and supplement our statistical analyses, we use event data and the case literature to outline the characteristics of street protests during Mubarak's tenure and provide an overview of the wave of mobilization that broke out during the post-Mubarak transition. We then introduce interview testimony, survey data, and other qualitative evidence to provide support for our hypothesis that protest can feature as a negative externality for broader publics during a democratic transition.

\section{Protest under authoritarianism}

The decade before the 2011 Arab Spring saw the emergence of new forms of oppositional politics in Egypt. In the early 2000s, support for the second Palestinian Intifada and opposition to the US-led invasion of Iraq led to the formation of new activist networks encompassing both secular and Islamist forces. These new connections led to petition campaigns and a series of small-scale protest initiatives that drew in university students and activist groups (Clarke 2011; Gunning and Baron 2013, chaps. 1-3). Still, this protest never scaled up to levels that threatened the regime or inflicted significant disruption. As Bishara $(2015,966)$ notes of mobilization under the Mubarak regime, street-level protest remained spatially contained and rarely lasted for more than a few hours (see also Bayat 2010, 212). Coeval to the emergence of these new protest initiatives was an upsurge in strike activity. Under the Mubarak regime, the Egyptian Trade Union Federation was the only legal trade union structure, and it worked to protect the interests of the state (Beinin and Duboc 2013, 207). Still, labor strikes became increasingly frequent from the mid-2000s onward, culminating in the formation of a nascent independent trade union movement spearheaded 
by Egypt's tax collectors (Beinin and Duboc 2013). But in the absence of national unions to coordinate strike action, much of this activism remained confined to individual workplaces and was circumscribed in terms of its duration and disruption (Barrie and Ketchley 2018, 182-84).

\section{Protest after the breakthrough}

If protest during the final decade of the Mubarak regime Egypt was episodic, localized, and relatively small in scale, this was to change dramatically in the aftermath of January 25, 2011, when several thousand activists outmaneuvered Interior Ministry-controlled security forces to stage a protest in Midan al-Tahrir in downtown Cairo. This marked the beginning of 18 days of energetic and bad-tempered protests in the streets and squares of Egyptian towns and cities calling for the downfall of the Mubarak regime (Gunning and Baron2013). During this period, a quarter of Egypt's police stations were burned down amid protests that saw local residents and activists inflict a bottom-up defeat on Mubarak's security apparatus (Ketchley 2017, chap. 2). Mubarak's resignation on February 11, 2011, would mark the beginning of a parlous democratic transition that unfolded under the direction of the Supreme Council of the Armed Forces (SCAF). In the immediate aftermath of Mubarak's departure, the SCAF promised to hold competitive parliamentary and presidential elections, as well as a referendum to amend the constitution. However, far from containing protest, the transfer of power to a transitional authority unleashed a wave of daily protests across the country, as workers, residents, activists, and university students took to the streets (see Barrie and Ketchley 2018).

The scale of protest during the post-Mubarak transition can be described using event data. In November 2010, two months before the outbreak of the January 25 Revolution, al-Masry al-Youm, at that time Egypt's largest and most reliable private newspaper, recorded 115 protests nationwide. For March 2011, two months after protestors first reached Midan al-Tahrir and more than a month after the ousting of Husni Mubarak, the same source reported on 655 protests, representing a nearly sixfold increase. As one prominent activist observed in the aftermath of Mubarak's ousting: "I used to hunt for where protests are, now everywhere I go there is one" (cited in Shenker 2016, 250). Not only was there a dramatic uptick in the frequency of mobilization, but protests also became much larger and lasted longer. In November 2010, protests only very rarely exceeded a few hundred protestors and typically ended within a few hours; by March 2011, events regularly attracted several thousand participants and could last for days or weeks. Particularly notable is the relative absence of organized po- litical Islam from this activism. Having participated in the January 25 Revolution, the Muslim Brotherhood, Egypt's largest social movement, endorsed the SCAF-run transition and demobilized to concentrate on elections (see Ketchley 2017, chap. 4). And so while the Brotherhood opted to pursue their interests through the ballot box, non-Islamist actors, including workers, students, and local residents, came to rely on street protest to advance their agenda.

\section{Unpopular protest}

There is good reason to think that this wave of mobilization may have affected political attitudes. In the weeks after $\mathrm{Mu}-$ barak's ousting, local newspapers record the first of a series of "anti-protest protests" by shopkeepers and local residents in Cairo, who complained that ongoing street-level mobilization was disrupting business and the flow of traffic in major thoroughfares (al-Masry al-Youm 2011a, 4; 2011b, 6; 2011c). ${ }^{2}$ In several of these early episodes, antiprotestors clashed with activists, who insisted that continued protest was necessary to deepen the gains from Mubarak's ousting. Media accounts of attempts by the military authorities to clear the protest occupation in Midan al-Tahrir also document disquiet about further mobilization. In early August 2011, shopkeepers and local residents are recorded as cheering as soldiers dismantled tents in an attempt to rid the square of protestors (Christian Science Monitor 2011). Citing traffic problems and the cost to the local economy, one local grocer insisted that "they [the protestors] must go home and give things a chance to get better. ... The sit-in makes things worse" (cited in Christian Science Monitor 2011). This sentiment is reflected in public opinion data: across three separate surveys fielded in the summer of 2011, a majority of Egyptians identified continued protest as negatively affecting the country (Younis and Younis 2011).

Disruptions in public service provision caused by protests also elicited public hostility. During a nationwide walkout by doctors and nurses in public hospitals in May 2011, Egyptian newspapers reported confrontations between hospital workers who staged sit-ins in front of hospital entrances and patients in several governorates (al-Masry al-Youm 2011f). Similarly, in June 2011, microbus drivers in the Nile Delta city of Mansoura attacked hospital workers who had blockaded a main road (al-Dostor 2011). Local media also documented physical altercations during a nationwide strike by government teachers in September. In the governorates of Suez and

2. This was a recurring complaint during the transition. In a survey fielded in Cairo in early 2012, 20\% of respondents identified traffic jams caused by protests as a source of stress and inconvenience (see Abdelmonem et al. 2015, 50). 
Beni Suef, parents are recorded as attacking teachers with bricks as they staged sit-ins, leading to the hospitalization of a head teacher (al-Masry al-Youm 2011g).

Economic fallout from protest features in many of these accounts. As Chalcraft $(2014,179)$ suggests, economic precariousness led many Egyptians to associate ongoing protest with socioeconomic threat and insecurity (see also Abdelmonem et al. 2015, 56). In one notable episode in Aswan, 600 workers employed in Egypt's tourism industry took to the streets to demand an end to further protest and the return of stability amid falling hotel occupancy rates (al-Ahram alMassa'i 2011). As one participant insisted: "it is time for life to return to normal, like before the 25th January [Revolution]" (cited in al-Ahram al-Massa'i 2011). In Damietta, where a local fertilizer factory was shut down after residents blockaded roads and staged sit-ins in protest of its environmental impact, factory workers staged a counterprotest criticizing the demonstrators and calling for the reopening of the factory. In an interview, one factory worker commented, "It won't work to go on like this, that every time a group goes out and stages protests we shut factories down for them.... We would end up closing all of Egypt's workshops and factories, then all of Egypt will end up sitting at home. . . Most of the young men you see here [at the counterprotest] took part in January 25th. Now we curse the day January 25th happened, even though we were in Midan al-Tahrir" (al-Wafd TV 2011).

A similar dynamic has been noted for Egypt's "revolutionweary middle class" (Kandil 2013, 18), who yearned for the stability and prosperity of the Mubarak era. This point is echoed in journalistic accounts of the transition, with residents calling for a strongman to curb protest amid increasing economic hardship (see Steavenson 2015, 80-81). Faced with mounting public criticism, several secular parties and activist movements announced that they would temporarily suspend their participation in protests, so as to minimize disruption to the local economy (al-Masry al-Youm 2011d, 2011e). The Muslim Brotherhood also picked up on popular disquiet about protest. Writing in its newspaper, the Brotherhood argued that "the people must protect the revolution by policing the political process and ceasing unnecessary protests and strikes... This way, the people can visualize a safe and secure exit from the transitional period" (cited in Ketchley 2017, 93).

While inevitably only a partial record of this period, these developments do point to an important precondition anticipated in our hypothesized relationship between high levels of protest and political attitudes during a transition. In Egypt, a recently authoritarian context where protest was hitherto small-scale and contained, sustained street-level mobilization had documented knock-on effects for broader publics, with many contrasting the upsurge in protest with life before the democratic breakthrough. And as the case details presented above suggest, this effect was sufficiently pronounced such that those affected by mobilization took to the streets to call for an end to further protest, while political parties demobilized for fear of alienating public opinion.

\section{DATA AND METHOD}

To study the effect of this protest on Egyptians' attitudes to democracy, we draw on the Arab Barometer survey and an event catalog of protest events recorded in Arabic-language newspapers. The Arab Barometer is a face-to-face survey conducted in Arabic. In total, 1,219 survey respondents were randomly selected from stratified sampling blocks; respondents came from 113 districts in 21 of Egypt's 27 governorates. Figure 1 shows the distribution of survey respondents by census district. (Note that the Arab Barometer does not survey the country's sparsely populated border governorates.) The survey was in the field from June 16 to July 3, 2011. This is ideally suited for our purposes. Egypt's democratic transition began on February 12, 2011, following the resignation of Husni Mubarak the day earlier. The subsequent period saw an unprecedented wave of mass protest as workers, activists, students, and local residents took to the streets. Importantly, the Arab Barometer was fielded before the election of an Islamist-dominated parliament and a Muslim Brotherhood candidate as president. This allows us to estimate the effect of protest on attitudes to democracy independent of popular misgivings about the subsequent performance of Egypt's newly elected democratic institutions.

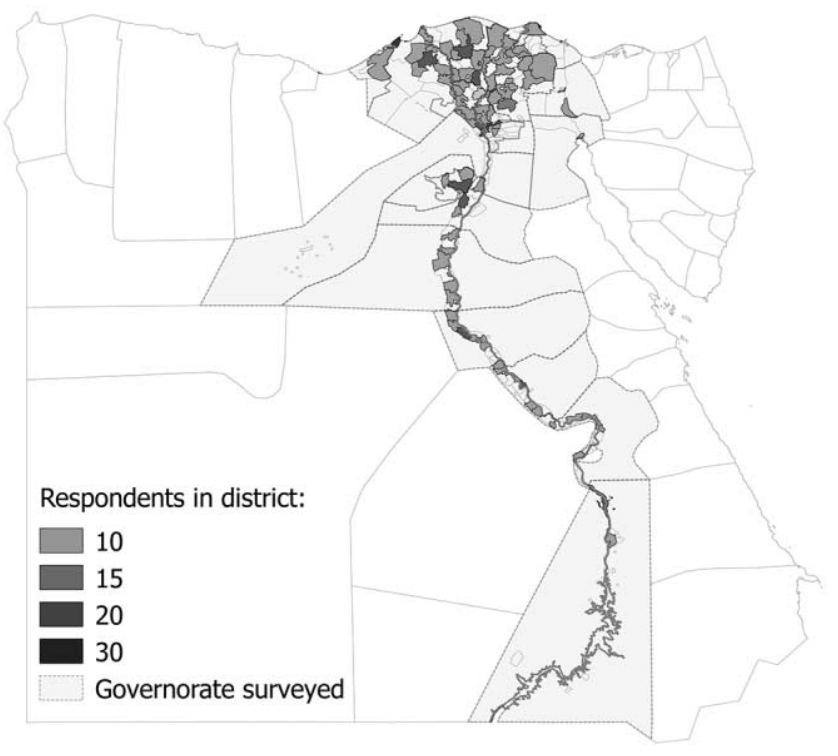

Figure 1. 2011 Arab Barometer survey respondents by district 
To account for variation in the incidence of protest, we draw on a catalog $(N=2,021)$ of protest events between February 12 and June 15, 2011, hand coded from two Arabiclanguage Egyptian newspapers, al-Masry al-Youm and alShorouq. These were two of the largest private newspapers in Egypt during this period, and both devoted considerable attention to chronicling local mobilization after Mubarak's ousting. When collecting our event data, we recorded who organized the protest, their repertoire, and the number of participants. $^{3}$ Events were then individually geolocated and assigned to their census district using a shape file (see fig. 2). For mobile protests such as marches and demonstrations, we geolocated the starting point of a protest. In total, 1,963 events ( $97 \%$ of all protest reported) can be reliably assigned to their census district. Of these, 1,727 protest events (88\%) can be georeferenced to their exact location. On 236 occasions (12\% of all geolocatable events), newspaper reporting only mentioned the village or district in which the protest occurred. For these cases, we assigned the protest to the village or district centroid. Our event data provide substantially greater coverage than any other comparable protest data set that is available for Egypt during the post-Mubarak transition. To give a comparison: the Armed Conflict Location and Event Dataset, which draws on English-language media reports, captures 230 protest events for this period. The most recent version of the Nonviolent and Violent Campaigns and Outcomes Data Project (NAVCO 3.0), which also relies on English-language media sources, contains records for only 102 protests.

We also draw on a separate catalog of protests in Egypt from September 2010 to the outbreak of the January $25 \mathrm{Rev}$ olution, derived from the Egyptian newspaper al-Masry alYoum. This allows us to account for any historic protest in a district in the period before Egypt's democratic breakthrough. To measure the destabilizing effect of the Revolution itself, we draw on a list of police stations attacked during the 18 days of protest (compiled by Ketchley 2017, chap. 2). The 2006 Egyptian census (the most recent census at that time) provides demographic information that accounts for population characteristics. Finally, we also use the WikiThawra (2013) data set that provides information on the home districts of protestors killed during the anti-Mubarak mobilization.

\section{Dependent variable}

Our unit of analysis is a survey respondent located in his or her census district; missing observations at the individual

3. Sometimes protest participation was not reported. In such cases we impute size from the repertoire using the coding rules set out in Ketchley (2017, 166).

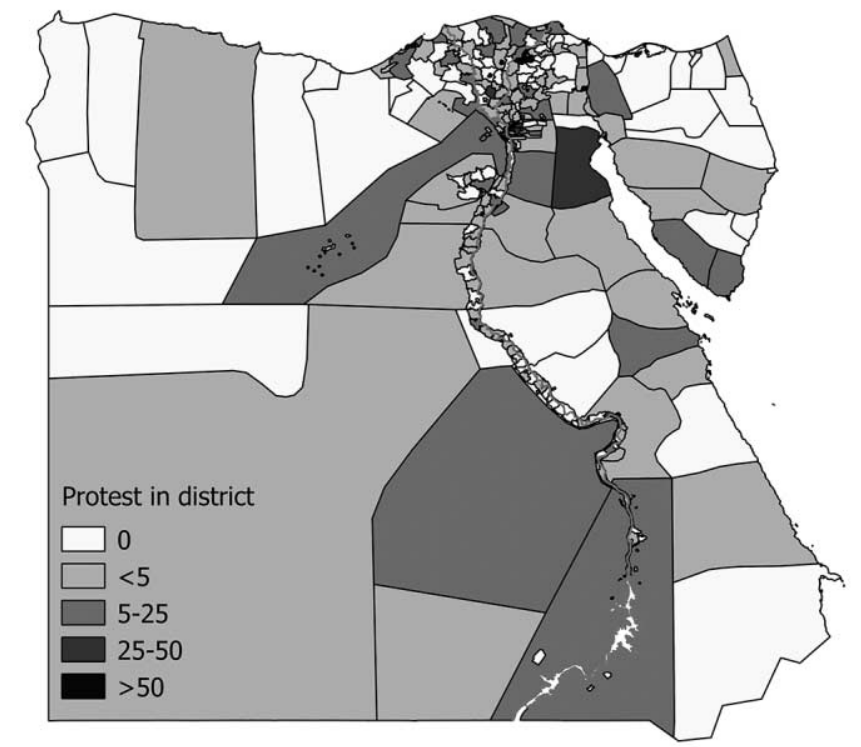

Figure 2. Protest events in district, February 12-June 15, 2011

level reduce the sample size to 1,040 individuals. Our main outcome of interest is a composite measure of attitudes to democracy using questions from the 2011 Arab Barometer. Here we take inspiration from Doherty and Schraeder (2018) and Hoffman and Jamal (2014) in analyzing a mean index of agreement with four statements designed to capture attitudes to democracy: "Under a democratic system, the country's economic performance is weak," "democratic regimes are indecisive and full of problems," "democratic systems are not effective at maintaining order and stability," and "democracy negatively affects social and ethical values in your country." This index is coded $0-4$, with higher values indicating more favorable attitudes to democracy (app. fig. 1 shows the distribution of respondents' attitudes; the appendix is available online). The index has a high coefficient of reliability $(\alpha=.85)$, and this provides confidence that these questions meaningfully capture the same underlying phenomenon. ${ }^{5}$ Ordinary least squares (OLS) regression models this as

$$
y_{i d g}=\alpha P_{i d}+X_{i d}+\delta_{g}+\varepsilon,
$$

where $y_{i d g}$ is the mean index of attitudes to democracy for survey respondent $i$ located in census district $d$ in governorate $g, P_{i d}$ is a count of protest events in a survey respondent's

4. To negate acquiescence bias, a positively framed question was introduced after the third question. Reassuringly, the mean difference in scores for the third and the fourth questions in our index is not statistically different from zero.

5. As per Doherty and Schraeder (2018), we coded "don't know" and other missing values to the midpoint of the scale, in order to preserve sample size. Our results are not altered if we use multiple imputation or drop "don't know" responses. 
census district, $X_{i d}$ is a vector of respondent- and district-level controls, and $\varepsilon$ is the error term. In Egypt, public services and local government functions are coordinated and delivered at the governorate level. To account for subnational variation in the quality of these services, as well as other betweengovernorate differences that are not captured by our control variables, a fixed intercept, $\delta_{g}$, is included in the regression, which absorbs the unique characteristics of each governorate. ${ }^{6}$ Analysis is thereby confined to variation in respondents' attitudes across districts within each governorate. The coefficient of interest throughout the analysis is $\alpha$, the effect of protest on attitudes to democracy. Following Abadie et al. (2017), standard errors are clustered at the treatment (census district) level.

\section{Independent variable: Local protest}

To account for the effect of protest on attitudes to democracy, we can locate survey respondents in their census district. As previously noted, the survey was fielded from June 16 to July 3, 2011. Unfortunately, the exact date that respondents were surveyed is not recoverable (Michael Robbins, pers. comm., December 28, 2018). To ensure that we are not capturing posttreatment protest, we measure mobilization in respondents' districts between the beginning of the democratic transition and June 15, 2011; the event catalog records protest in the home districts of 889 survey respondents (73\%). The mean number of protests in a respondent's district during this period was 5 ; the maximum was 77 . Our measure of protest is therefore a count of protest events in a census district. We expect that the effect of protest will have diminishing marginal returns, and so we transform this to the square root. ${ }^{7}$ In subsequent analyses, reported after our main results, we test alternative protest measures and disaggregate the effects of protest by repertoire, sector, and participation.

\section{Instrumental variable: Distance to a focal point}

We are concerned that an individual's propensity to encounter protest may be endogenous to his or her assessment of democracy. We therefore incorporate a two-stage, instrumental variable design into our analysis. Specifically, we hypothesize that experience of protest during the post-Mubarak democratic transition was likely influenced by protest ecologies that emerged during the 18 days of the January $25 \mathrm{Rev}$ olution, when public squares and major thoroughfares - most

6. The intraclass correlation obtained from the null model shows that $11 \%$ of variation in attitudes to democracy is explained by betweengovernorate differences. The chi-squared statistic from a likelihood-ratio test confirms that a multilevel structure is appropriate $(\mathrm{LR}=82.69, p=.000)$.

7. We also tested an unbounded count and other functional forms; all produce statistically and substantively similar results. famously Midan al-Tahrir in downtown Cairo-emerged as focal points for mobilization in governorates across the country (Gunning and Baron 2013). To help us identify focal points, which we define as the most frequently recurring location for street protests in a governorate during the January 25 Revolution, we drew on event data derived from Arabiclanguage newspapers collected by Ketchley (2017).

In the post-Mubarak period, these spaces were frequently memorialized in local media reporting as "squares of the revolution" and continued to serve as focal points for collective protest during the transition (see Barrie and Ketchley 2018; Ketchley 2017, chaps. 4 and 5). Here protestors from across the political spectrum followed a repertoire in which protests set off from mosques and other associational spaces moved through commercial and residential areas, before arriving at a focal point for protest. Areas in and around focal points also became sites for mobilization. We exploit this convenient feature of Egyptian contentious politics to account for possible endogeneity and omitted confounders. In this, our instrumental variable regression employs an exclusion restriction similar to that adopted by Acemoglu, Johnson, and Robinson (2001): conditional on a vector of individual- and district-level controls included in the regression, survey respondents living closer to a focal point will be more likely to encounter protest than those living farther away, simply as a result of their proximity. It follows that shorter distances to a focal point will be more likely to receive the treatment effect.

This logic is illustrated in figure 3, which records survey respondents' spatial relationship to Midan al-Tahrir in downtown Cairo. We hypothesize that survey respondents

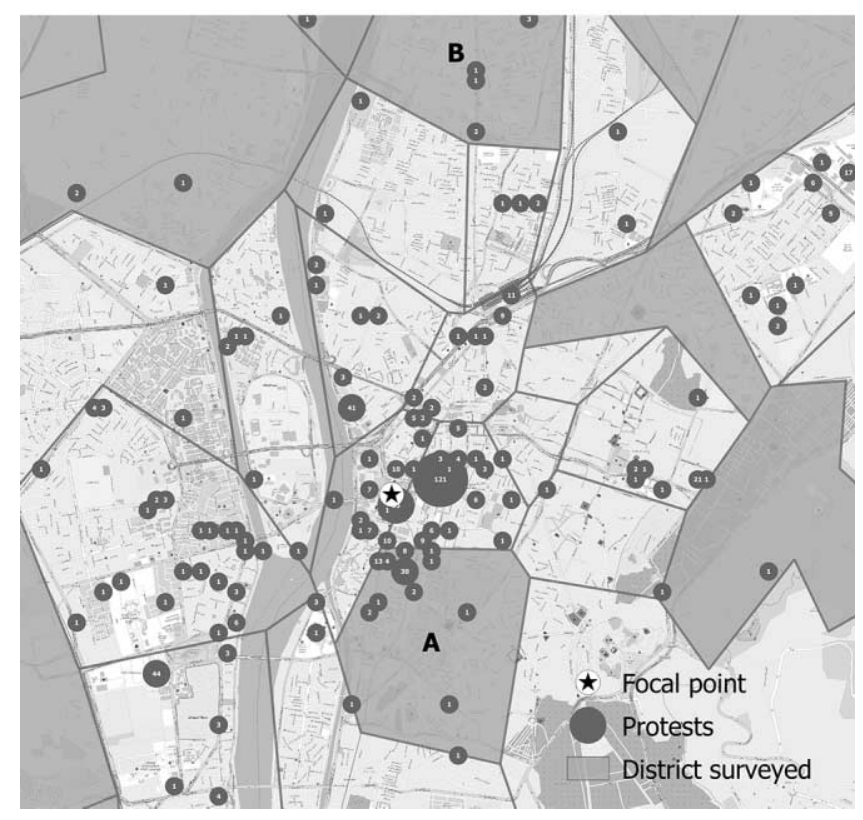

Figure 3. Focal point and survey respondents' districts in Greater Cairo 
Table 1. Effect of Distance to a Focal Point on Protest in a District

\begin{tabular}{|c|c|c|c|c|}
\hline & Model 1 & Model 2 & Model 3 & Model 4 \\
\hline Distance to a focal point (sqrt, km) & $\begin{array}{c}-.366^{* * *} \\
(.103)\end{array}$ & $\begin{array}{c}-.396^{\star * *} \\
(.117)\end{array}$ & $\begin{array}{c}-.340^{\star * *} \\
(.091)\end{array}$ & $\begin{array}{c}-.352^{\star * *} \\
(.102)\end{array}$ \\
\hline$X_{i d}$ & & & $\checkmark$ & $\checkmark$ \\
\hline$\delta_{g}$ & & $\checkmark$ & & $\checkmark$ \\
\hline$R^{2}$ & .15 & .30 & .40 & .51 \\
\hline$N$ & 1,219 & 1,219 & 1,040 & 1,040 \\
\hline
\end{tabular}

Note. Ordinary least squares regression; cluster-robust standard errors in parentheses; two-tailed $p$-values.

${ }^{*} p<.10$.

$* * p<.05$.

${ }^{* * *} p<.01$.

living in Sayeda Zainab (marked with the letter A in fig. 3) saw more protest than respondents in Shubra (shown as B), in part, because they lived closer to a focal point. We measure this as the distance in kilometers from a district centroid to the nearest focal point; the mean distance was 20 kilometers, while the maximum was 101 kilometers. Again, we expect that the effect of distance to a focal point is subject to diminishing marginal returns, and so we transform this variable to the square root. ${ }^{8}$ Two-stage least squares (2SLS) estimates of equation (1) are presented below. Our counts of protest activity in a survey respondent's district, $P_{i d}$, are treated as endogenous to a respondent's assessment of democracy, and so modeled as

$$
P_{i d}=\beta D_{i d}+X_{i d}+\delta_{g}+\nu,
$$

where $D_{i d}$ is the distance between a survey respondent's district and a focal point for mobilization.

Table 1 provides a series of reduced-form tests of our instrumental variable on the occurrence of protest, as well as a test including controls (detailed below) equivalent to the first stage of the 2SLS regression. As the OLS estimates show, our intuition that proximity to a focal point conditions the likelihood of protest receives confirmation: increasing distance to a focal point significantly and substantively reduces the frequency and scale of protest in a district. Figure 4 provides a visualization of the first-stage estimates from model 4. To give an illustration: increasing the distance to a focal point from 1.6 (the 5 th percentile) to 45.3 kilometers (the 95th percentile) reduces the predicted incidence of protest in a census district by $73 \%$.

8. Distances are great circle. Our instrumental variable regressions are robust to an untransformed measure of distance, as well as alternative functional forms.
For our instrumental variable to be valid, not only must it affect the likelihood of respondents receiving the treatment, but the political composition of districts that are more proximate to focal points must not systematically differ in ways that might affect attitudes to democracy and that are not blocked by controls. Table 2 probes this with several bivariate placebo tests. ${ }^{9}$ The outcome measures are taken from the 2005 parliamentary elections (the last semicompetitive elections before the 2011 transition). The result from model 5 shows that distance to a focal point does not contribute significantly to the election of a member of Parliament (MP) from Mubarak's National Democratic Party (NDP). Similarly, model 6 suggests that our instrument does not significantly predict the presence of a strong NDP electoral machine, as proxied by an NDP politician being elected without having to go into a second-round runoff. Finally, as per model 7, distance to a focal point is not statistically related to the election of a Muslim Brotherhood MP.

\section{Controls}

To account for factors associated with both a respondent's attitude to democracy and relationship to protest, we include in the model a vector of individual- and district-level controls (app. tables 1 and 2 are the descriptive statistics and the correlation matrix). Prior research has found relationships between support for democracy in the Middle East and North Africa (MENA) region and a range of demographic factors (see, e.g., Al-Ississ and Diwan 2016; Jamal 2006; Mazaheri and Monroe 2018; Tessler 2002). Following that literature, we enter variables for a respondent's age, age squared, gender, religion, religiosity (measured as how often

9. Note that we use placebos checks as there is currently no statistical test for the exclusion restriction of a continuous endogenous variable (see Gunsilius 2018). 


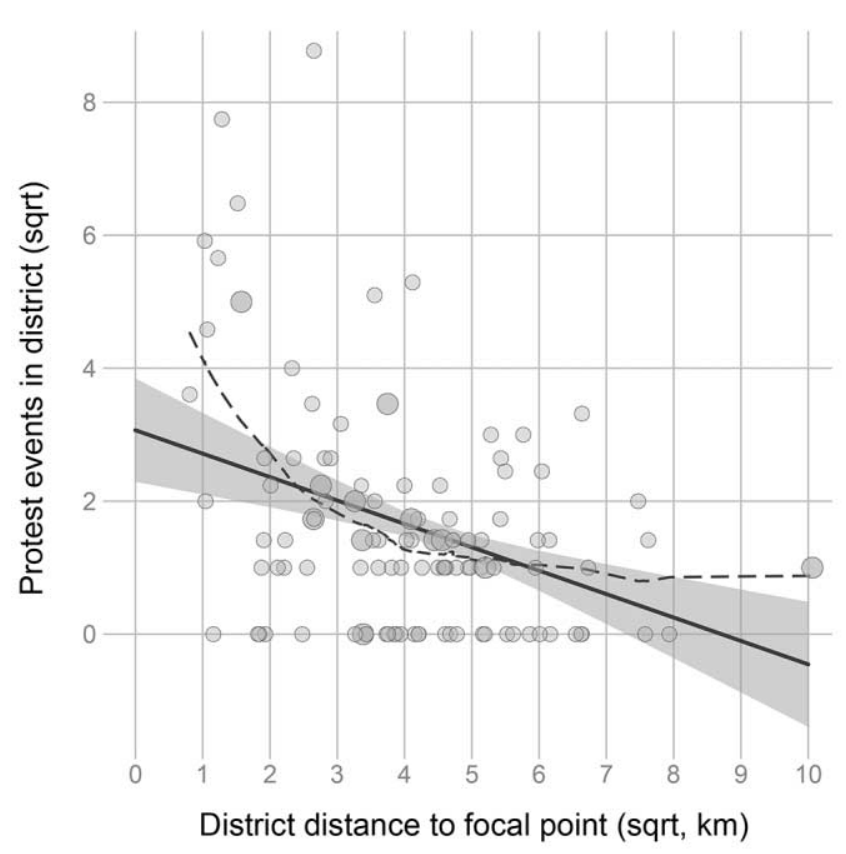

Figure 4. First-stage estimates. Solid line, ordinary least squares regression. Dashed line, locally weighted scatter plot smoother. Points are the real values with size proportional to the number of survey respondents in a district.

an individual reads a religious text), level of education, employment status, business ownership, and income (transformed by taking its logarithm to the base 10).

We also control for a range of individual- and district-level characteristics that may be correlated with a respondent's attitude to democracy and the likelihood that he or she will encounter protest. We expect that protest will be more likely in built-up urban areas, and so we enter a variable measuring a district's population density, in thousands per kilometer, and a dummy variable for whether that district is urban. We also expect that there will be more opportunities to protest in the capital city, where there may also be more support for democracy, and so we measure a district's distance in kilometers to central Cairo, transformed to the square root. To account for districts with a recent history of mobilization, we enter a dummy variable for whether any protest occurred in a survey respondent's district in the four months before the January 25 Revolution. The number of protestors from a district killed during the January 25 Revolution allows us to control for protest-prone populations with ongoing grievances, again taken to the square root. To capture the destabilizing effects of the January 25 Revolution and ongoing opportunities to protest, we enter a dummy variable for whether the police station was attacked in a respondent's district during the 18 days of mobilization.

The Arab Barometer contains a number of questions that capture attitudes toward both protest and democracy from
Table 2. Effect of Distance to a Focal Point on a District's Political Composition

\begin{tabular}{rccc}
\hline & $\begin{array}{c}\text { Model 5 } \\
\text { NDP Elected }\end{array}$ & $\begin{array}{c}\text { Model 6 } \\
\text { NDP Strong }\end{array}$ & $\begin{array}{c}\text { Model 7 } \\
\text { MB Elected }\end{array}$ \\
\hline Distance to a focal & & & \\
point (sqrt, km) & .017 & -.019 & -.008 \\
& $(.028)$ & $(.021)$ & $(.026)$ \\
$R^{2}$ & .004 & .010 & .001 \\
\hline
\end{tabular}

Note. Ordinary least squares regression; cluster-robust standard errors in parentheses; two-tailed $p$-values. NDP = National Democratic Party; $\mathrm{MB}=$ Muslim Brotherhood. $N=1,219$.

${ }^{*} p<.10$.

${ }^{* *} p<.05$.

${ }^{* * *} p<.01$.

which we construct a series of additional control variables. If Egyptians updated their assessment of democracy because of protest, this is self-evidently conditional on the degree to which they perceived Egypt to be democratizing following Mubarak's ousting. To account for this, we enter an ordinal variable that records respondents' assessment of Egypt's democratic development at the point when they were surveyed. To capture prior support for authoritarianism, we enter a dummy variable for survey respondents who sided with the Mubarak regime during the January 25 Revolution. To capture prior attitudes to procedural democracy, we control for whether a survey respondent voted in previous elections. To control for attitudes to protest, we enter dummy variables for respondents who participated in the January 25 Revolution or who provided material support to the revolutionaries, as well as a dummy variable for respondents who reported protesting during the post-Mubarak transition. Finally, state media in Egypt demonized both the January 25 Revolution and calls for political liberalization (Lindsey 2011), and so we construct a dummy for whether a respondent reported a state media outlet as his or her principal news source.

\section{RESULTS}

Table 3 shows our initial results. Model 8 begins with the OLS coefficients. Our hypothesis that the level of local protest adversely affects attitudes to democracy receives initial support: when comparing respondents from the same governorate, Egyptians living in districts with more protest held more negative attitudes to democracy. The effect size is nontrivial. To give an illustration: moving location from a district at the 5th percentile of protest to a district at the 95th percentile of protest is associated with an $8.5 \%$ reduction in how respondents scored democracy. 
Table 3. Effect of Protest on Attitudes to Democracy

\begin{tabular}{|c|c|c|c|}
\hline & \multirow{2}{*}{$\begin{array}{c}\text { Model } 8 \\
\text { No } \\
\text { Instrument: } \\
\text { OLS }\end{array}$} & \multicolumn{2}{|c|}{ Model 9} \\
\hline & & $\begin{array}{c}\text { First Stage: } \\
\text { OLS }\end{array}$ & $\begin{array}{c}\text { Second } \\
\text { Stage: 2SLS }\end{array}$ \\
\hline $\begin{array}{l}\text { Protest events } \\
\quad \text { (sqrt) }\end{array}$ & $\begin{array}{c}-.046^{* * *} \\
(.016)\end{array}$ & & $\begin{array}{c}-.139^{\star *} \\
(.063)\end{array}$ \\
\hline $\begin{array}{l}\text { Distance to } \\
\text { focal point } \\
\text { (sqrt, km) }\end{array}$ & & $\begin{array}{l}-.352^{* * *} \\
(.102)\end{array}$ & \\
\hline$X_{i d}$ & $\checkmark$ & $\checkmark$ & $\checkmark$ \\
\hline$\delta_{g}$ & $\checkmark$ & $\checkmark$ & $\checkmark$ \\
\hline$R^{2}$ & .24 & $\ldots$ & $\ldots$ \\
\hline $\begin{array}{l}\text { Kleibergen-Paap } \\
\text { Wald F-statistic }\end{array}$ & $\ldots$ & 12.01 & $\ldots$ \\
\hline
\end{tabular}

Note. Cluster-robust standard errors in parentheses; two-tailed $p$-values. OLS $=$ ordinary least squares; 2 SLS $=$ two-stage least squares. $N=$ 1,040 .

${ }^{*} p<.10$.

$* * p<.05$.

${ }^{* * *} p<.01$.

Model 9 introduces our instrumented regressor, with coefficients from both the first-stage OLS and second-stage 2SLS estimates reported. ${ }^{10}$ When compared to model 8, the estimated 2SLS coefficient is larger and equivalent to the local average treatment effect. Our hypothesis receives further support: respondents living in districts with higher rates of protest held significantly and substantively less favorable perceptions of democracy when compared to respondents from the same governorate who lived in districts with lower rates of protest. Figure 5 shows the marginal predicted effect of protest using estimates from model 9, with all other covariates held at their mean values. A rug plot shows the marginal distribution of protest on the $X$-axis. The confidence intervals are larger at higher values, as very intense protest is concentrated in just a few districts, and so information is more sparse. Increasing the scale of protest in a district from the 5 th to the 95 th percentile is associated with a $24 \%$ decrease in how respondents scored democracy. This association is even more pronounced at higher values. For survey respon-

10. A digression on regression diagnostics is germane: the clusterrobust $F$-statistic is greater than 10, Kleibergen-Paap's LM statistic for underidentification is statistically significantly different from zero, and Hansen's J statistic is statistically significant.

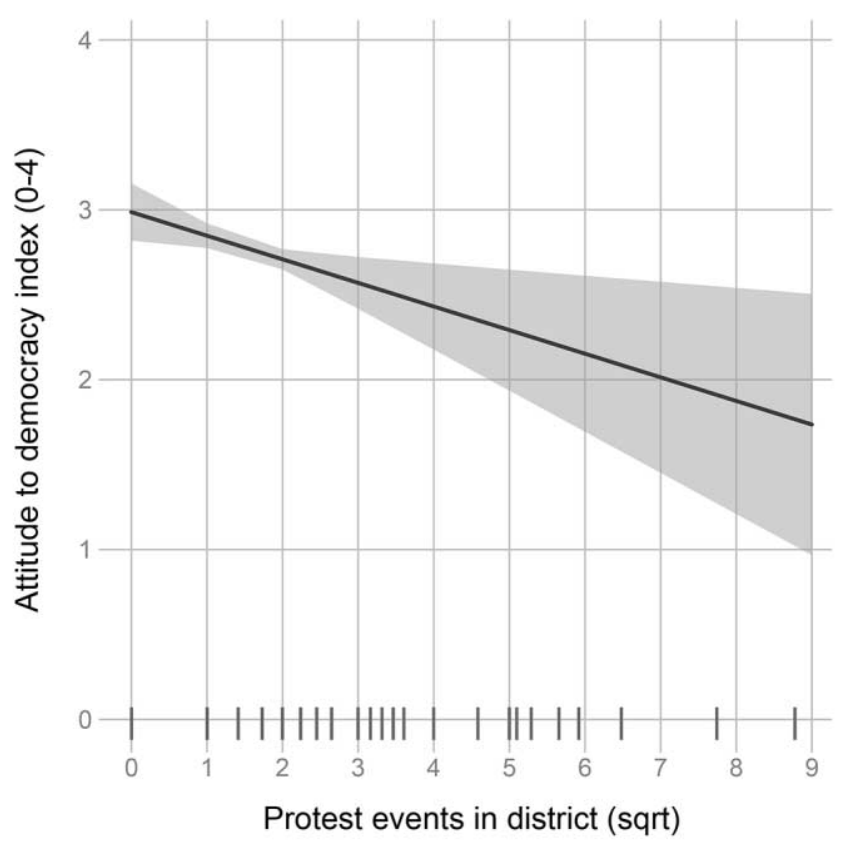

Figure 5. Effect of protest on attitudes to democracy

dents at the 99th percentile-indicating an individual living in a district where there was a protest nearly every other day averaged over a four month period-the estimated score is reduced by $36 \%$.

Models $10-17$ in appendix tables 3 and 4 provide an alternative analysis, decomposing our dependent variable into its constituent questions. Decomposing our dependent variable provides confidence that no single question is driving our findings. The effect of protest on each measure of democracy is modeled using both OLS and 2SLS instrumental variable regressions. In models 16 and 17 , the coefficients are negative but are not statistically significant $(p=.18$ and $p=.10$, respectively). ${ }^{11}$ In all other models, higher rates of protest in a census district are negatively and significantly associated with a respondent's assessment of democracy. In the OLS models, a greater incidence of protest is particularly associated with democratic regimes being perceived as indecisive and ineffective at maintaining order. In the 2SLS models, higher levels of protest are most strongly associated with democracies having weaker economies, a point that we return to after our robustness checks. These results suggest that within four months of Mubarak's ousting, Egyptians living in high-protest districts were more likely to associate democratic regimes with a range of negative characteristics.

11. Note that the effect of protest in both models is significant at margins $(p=.001)$. 


\section{ROBUSTNESS AND ALTERNATIVE SPECIFICATIONS}

Appendix tables 5-10 provide checks for the robustness of our findings, as well as alternative specifications. One obvious concern relates to missingness. List-wise deletion removes 179 survey respondents (14\% of the sample) from our analysis. To ensure that our findings are not artifactual of this process, we use multiple imputation to account for missing information. The results are reported in model 18 . Reassuringly, after recovering information lost because of incomplete observations, the number of protest events in a district remains significantly negatively associated with attitudes to democracy.

So far, our analysis has looked at the absolute rate of protest. Following Abadeer et al. (2019), we can also look at changing experiences of protest in a district using prebreakthrough levels of mobilization as the baseline. To do this, we subtract the daily rate of protest in a district in the four months before the January 25 Revolution from the daily rate of protest in a district during the four months of the transition. The results, reported in models 19 and 20, show that an increase in the incidence of protest in a district relative to the Mubarak-era baseline is associated with significantly less favorable attitudes to democracy. Further tests, shown in models 21-24, include alternative specifications of our main protest variable. As outlined earlier, the $2011 \mathrm{Arab}$ Barometer does not record the precise date that survey respondents were interviewed. In consequence, we measured mobilization in a census district between the first day of the democratic transition and the day before fielding the survey. This excises the effect of any protest that occurred during the survey period. To account for this, in models 21 and 22 we enter control variables for protest events that occurred in a district during the survey period. In models 23 and 24, we test an alternative variable that captures all protest between February 12 and July 3, 2011 (the end of the survey period). Note that these variables are inferior, as we cannot reliably exclude protest that is effectively posttreatment. Regardless, across all models a greater incidence of protest in a respondent's district remains significantly negatively associated with attitudes to democracy.

Another concern relates to respondents' attitudes to democracy: two subcomponents of our index ask respondents to assess democracy's ability to deliver economic growth and maintain order and stability. We have already decomposed our dependent variable and found that when analyzed separately, protest remains negatively correlated with each subcomponent of the index. To further parse the effect of protest during the transition from the general instability caused by Mubarak's ousting, we enter dummy variables for respondents who judged that the economic and security situation in
Egypt had deteriorated as a result of the January 25 Revolution. Again, our results are unchanged. Our principal findings are also unaffected if we control for whether a respondent planned to vote for the Muslim Brotherhood in the 2011 parliamentary elections. We also account for additional districtlevel political characteristics. In particular, we use our measures from the 2005 parliamentary elections to control for whether respondents lived in areas where an NDP candidate was elected as an MP without facing a runoff, as well as whether a district elected a Muslim Brotherhood candidate. Including these variables in the regression does not affect our headline results. ${ }^{12}$

As per models 25 and 26, to be confident that our findings are not artifacts of our choice of control variables, we use the Lasso (least absolute shrinkage and selection operator) to estimate reduced OLS and instrumental variable models. Model 27 is a stepwise backward OLS model, where statistically insignificant covariates are removed if $p>.05$. Models 2831 are weighted least squares regressions that incorporate poststratification sample weights for our control variables. Across all of these models, a greater incidence of protest remains significantly negatively associated with attitudes to democracy. Finally, in models 32 and 33 we estimate multilevel OLS models, substituting governorate-level fixed effects with random intercepts at both the governorate $\left(\zeta_{g}\right)$ and district $\left(\zeta_{d}\right)$ levels. In both models, a higher level of protest in a respondent's district is a negative and significant predictor of attitudes to democracy.

\section{REPERTOIRE, SECTOR, AND SIZE}

So far our analysis has treated protest as a unitary phenomenon. Following Branton et al. (2015) and Wallace et al. (2014), we should also examine how attitudes to democracy were affected by different protest tactics, the identities of the protestors, and protest participation. To do this, we disaggregate our key independent variable of interest: the level of protest in a respondent's district.

Appendix table 11 tests how different protest repertoires patterned attitudes to democracy. Half the protests during our analysis period were labor protests, but strikes constituted only $20 \%$ of labor events. The balance were public forms of street-level mobilization. We classify these repertoires on the basis of their abstract characteristics: strikes are self-explanatory; demonstrations and marches were more transitory forms of street protest; and blockades, sit-ins, and occupations involved the taking over of public space and typically lasted several hours or more. These variables are highly correlated with each other (maximum pair-wise

12. The outputs are available from the authors. 
$r=.73$ ), and so we begin by entering each one individually. The results are revealing. Egyptians living in districts that saw more blockades, sit-ins, and occupations held more negative assessments of democracy. We find a similar association for Egyptians living in areas that saw more street marches and demonstrations. The coefficient for strikes is negative, but it does not achieve statistical significance. For reference we include a model with all variables estimated together. Recall that these measures are highly correlated with one another. Regardless, a higher number of blockades, sit-ins, and occupations remains significantly negatively associated with attitudes to democracy. ${ }^{13}$ However, the number of marches and demonstrations loses significance.

Appendix table 12 examines the effects of protest by different sectors. We enter counts of protest events launched by labor, students, local residents, and activists. These categories capture $77 \%$ of all recorded protests. Egyptians living in districts with higher levels of labor protests held significantly less favorable attitudes to democracy. Higher rates of student protest in a district are also significantly negatively associated with attitudes to democracy. Interestingly, protests launched by activists are actually modestly positively associated with attitudes to democracy, although this measure does not approach statistical significance $(p=.79) .{ }^{14}$ Higher rates of protest by local residents have no effect. When modeled together, our measure for the number of student protests is no longer statistically significant.

These tests expand on our initial findings and suggest that an aggregate measure of protest is measuring the true relationship with error. Parsing our measure of protest suggests that street protests involving the occupation and disruption of public space were especially deleterious to Egyptians' perceptions of democracy. Such static protests oftentimes lasted for several hours or days, and so had a greater impact on broader publics. The role played by labor protest requires further consideration. On the one hand, the high number of labor events during this period helps to explain the pronounced negative relationship between sustained mobilization and the perception that democracies have weak econo-

13. The importance of blockades, sit-ins, and occupations is also confirmed if we decompose our dependent variable into its constituent questions. A higher rate of this protest type in a district is significantly negatively associated with respondents linking democracy with a weak economy, indecisive government, and disorder and instability. The question related to social and ethical values does not achieve significance.

14. This chimes with Gallup's survey data from the summer of 2011 (Younis and Younis 2011): while a majority of Egyptians thought that protest was harming the country, those who had spearheaded the January 25 Revolution continued to enjoy widespread popularity. mies. This suggests that Egyptians conceived of disruption not only in terms of instability and chaos but also in terms of its impact on people's livelihoods and the broader economy. On the other hand, it seems that attitudes to democracy were most affected by labor's use of the January 25 repertoire of disrupting public space. This is confirmed by additional analyses reported in appendix table 13. Disaggregating labor protests by repertoire, a higher incidence of labor protests that involved blockades, sit-ins, and occupations is a substantive and significantly negative predictor of attitudes to democracy. By comparison, strikes, the least visible type of protest to local residents, have a more ambiguous effect.

What role did elite demonization play here? During the January 25 Revolution, Husni Mubarak had repeatedly invoked the threat that protest posed to stability in a bid to demobilize antiregime opposition and calls for democratization (Makram Ebeid 2012). And this rhetoric was taken up by the SCAF in the aftermath of Mubarak's departure. As Sallam (2011) has documented, state officials and agencies particularly singled out labor protests for criticism, which were portrayed as narrowly sectoral and deleterious to the country's economic health. While elite demonization of protest may have led some Egyptians to turn against street-level activism, this seems less relevant when explaining variation in how Egyptians came to view democracy. As our statistical results show, Egyptians living in areas where there was little to no protest, labor or otherwise, held much more positive perceptions of democracy. This is after controlling for proMubarak attitudes and whether respondents received their news from state media - the principal channel for disseminating SCAF talking points. Interaction terms between different measures of protest in a district and consuming state media have no effect. This suggests that proximity to protest during a transition can exert an effect on political attitudes that is independent of old regime attempts at casting mobilization, and by extension democratization, in a negative light.

We now turn to aggregate protest participation in a district. Note that this is a less direct test of our hypothesis, as small to medium but continuous protest over a protracted period likely inflicts a greater degree of disruption than a one-off protest that attracts a very large number of participants. This is evident when looking at participation by repertoire. As we saw above, a higher frequency of blockades, sit-ins, and occupations has the most consistent effect on attitudes. And yet, a typical blockade, sit-in, or occupation attracted around 400 protestors, no doubt reflecting the difficulty in sustaining large numbers in one place for an extended period. By contrast, mean participation on a demonstration or march was around 2,700 participants; nearly seven 
times larger. The average strike involved around 500 participants. Appendix table 14 probes this further. Models 47 and 48 are the OLS and 2SLS results. The coefficient for aggregate protest participation is negative in both models, but it is only statistically significant in model 48 . Parsing aggregate protest participation by repertoire, we find that higher participation in blockades, sit-ins, and occupations is again significantly negatively associated with attitudes to democracy. A higher number of protestors participating in marches and demonstrations, on average the largest type of protest by repertoire, has no effect. A higher number of strikers in a district is also negatively associated with how respondents scored democracy. However, when modeled together, none of these variables is significant, and the measure for participation in marches and demonstrations turns positive. On balance, these results suggest that our key findings are driven by a higher frequency of longer-lasting, static protests that had greater potential to disrupt public space, as opposed to larger, more ephemeral protests.

\section{CONCLUSION}

Before reflecting on our findings, we should acknowledge their limitations. Our analysis provides only a snapshot of how protest affects attitudes to democracy four months into a democratic transition. Ideally, we would have panel data available to test how protest patterns attitudes to democracy over time - and account for how protest shaped substantive democratic behavior, such as whether respondents voted in the Egypt's founding elections and, if so, how they voted. ${ }^{15}$ Of course, our measure of protest relies on assignment to an aggregated geographic unit. A superior approach would be to estimate individual-level treatment effects using spatial buffers (e.g., Wallace et al. 2014). Unfortunately, the geospatial information required to construct these buffers is not available for the Arab Barometer or, to the best of our knowledge, any other survey that was fielded in Egypt during the first year of the post-Mubarak transition. In mitigation, our approach has the great strength of providing the first

15. The 2011 Arab Barometer does include a question on future voting intentions. Controlling for whether a respondent voted in a previous election, logistic regression suggests that Egyptians living in high-protest districts were more likely to vote in the 2011 parliamentary elections-although this does not quite achieve statistical significance $(p=.12)$. One interpretation is that such individuals intended to vote for old regime candidates: in the summer of 2011, NDP politicians were expected to win up to a third of seats (Kandil 2011). Appendix table 12 provides some tentative evidence for this reading: more protest in a district predicts greater support for Ahmad Shafiq in the 2012 presidential elections. Respondents were also asked who they would vote for, but this information is too sparse ( $8 \%$ replied) to draw meaningful inferences. systematic analysis of how street-level mobilization shapes popular attitudes to democracy over a political transition.

Our results suggest that four months into the transition, sustained protest had already begun to negatively affect Egyptians' attitudes to democracy. We find no evidence for the alternative proposition: that protest endeared Egyptians to democracy. We argue that this negative association is plausibly attributed to the nature of protest and the context of a political transition in a recently authoritarian country. For protestors to achieve their aims, they must necessarily inflict a cost on authorities, and inevitably these efforts have consequences for broader publics, who, while not the targets of mobilization, are nevertheless affected by mobilization. Qualitative details from the Egyptian case attest to this fallout, and disaggregation of our protest measure highlights the importance of street-level protest that involved disrupting space. Sensitivity to the negative externalities of this mobilization, we suspect, is likely heightened in a recently authoritarian context in which prior protest was previously small in scale and spatially contained. In such settings, where citizens are updating their assessment of how democracy may work in practice, high levels of localized protest can lead some to associate democracy with the knock-on effects of sustained mobilization.

What is the significance of our findings for understanding the position of protest in processes of democratization? Mass mobilization following a democratic breakthrough is not uncommon to successful third-wave democratic transitions (see, e.g., Ekiert and Kubik 1999). This suggests that any decline in support for democracy because of disruptive protest can only ever be a contributing but not sufficient condition in scotching a democratic transition. It does, however, help to illuminate the conditions under which democratic reversals can occur. As Jou (2016) has argued, in transitional contexts, where regime stability cannot be taken for granted, popular support for democracy can help insulate a transition from negative political or economic shocks. This builds on a central insight from the early literature on third-wave democratization: successful consolidation requires popular acceptance of the idea that democracy is the "only game in town," rather than one of several governing options (Linz and Stepan 1996). And as recent episodes of failed democratic transition illustrate, popular disillusionment with democratization can be harnessed by old regime figures to roll back democratic gains and bring about authoritarian retrenchment (for a review, see Haggard and Kaufman 2016). However, the question of how support for democracy develops or is eroded during periods of democratic transition is often ambiguous.

Egypt's democratic transition failed on July 3, 2013, when a military coup seized on mass protests to oust Islamist 
president Muhammad Mursi. In explaining support for democracy in the MENA, most studies focus on factors that predate democratic openings. By contrast, this article finds that sustained mobilization during the transition itself may have contributed to the erosion of popular support for Egypt's new democracy by sapping the public's confidence in the capacity of the new democratic regime to guarantee a return to prebreakthrough levels of economic prosperity and resolve social conflict. Further examination of this dynamic can, we suggest, help to explain when and how popular disillusionment with democratization is harnessed by old regime figures to engineer democratic reversals.

\section{ACKNOWLEDGMENTS}

An early version of this article received detailed feedback from the Comparative Politics Working Group at the University of North Carolina at Chapel Hill. Christopher Barrie, Catherine Boone, Killian Clarke, Ferdinand Eibl, Marco Giani, Jonathan Hartlyn, Steffen Hertog, Jalal Imran, Kay Jowers, Ali Kadivar, Gabriel Leon, Gary Marks, Aaron Reeves, Graeme Robertson, John Sidel, Tore Wig, and three anonymous reviewers gave valuable comments and suggestions. We also thank Margit Tavits for her feedback and guidance. Rania AbdelNaeem, Steven Brooke, and Sarah ElMasry generously shared data on the 2005 Egyptian elections, while Michael Robbins provided us with a restricted version of the Arab Barometer and patiently answered questions about the survey methodology.

\section{REFERENCES}

Abadeer, Caroline, Alexandra Domike Blackman, Lisa Blaydes, and Scott Williamson. 2019. "Did Egypt's Post-uprising Crime Wave Increase Support for Authoritarian Rule?” Working paper.

Abadie, Alberto, Susan Athey, Guido W. Imbens, and Jeffrey Wooldridge. 2017. "When Should You Adjust Standard Errors for Clustering?" NBER Working paper no. 24003, National Bureau of Economic Research, Cambridge, MA.

Abdelmonem, Deena, Salma N. Mohamed, Tiya Abdel-Malek, Seham Kafafi, Salma Khalifa, Rana Khalil, Bosma Abdelaziz, and Mona M. Amer. 2015. "Tumult, Trauma, and Resilience: Psychological Well-Being of Cairenes One Year Following the January 25, 2011 Uprisings.” In Nicholas Hopkins, ed., The Political Economy of the New Egyptian Republic. Cairo: American University in Cairo Press.

Acemoglu, Daron, Simon Johnson, and James A. Robinson. 2001. "The Colonial Origins of Comparative Development: An Empirical Investigation." American Economic Review 91 (5): 1369-401.

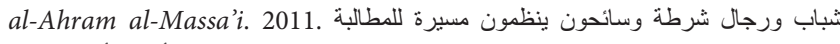
بعودة الاستقر ار الأمني لأسوان April 10. http://massai.ahram.org.eg/Archive /Inner.aspx?ContentID = 30641 (accessed September 10, 2018).

al-Dostor. 2011. اشتباكات بين عمال مستشفى جامعة المنصورة المعتصمين وسائقي السيار ات ات June 2. https://www.masress.com/dostor/43989 (accessed March 27, 2019).

Al-Ississ, Mohamad, and Ishac Diwan. 2016. "Preference for Democracy in the Arab World." Politics and Governance 4 (4): 16-26.
al-Masry al-Youm. 2011a. تصاعد الاشتباكات في التحرير ومصطفى محمود بين مؤيدي الاعتصام ومعارضيه. March 8.

al-Masry al-Youm. 2011b. مسيرة سلفية وأخرى نسائية في التحرير ومشادات بين المعتصمين والمطالبين بإخلاء الميدان. March 9.

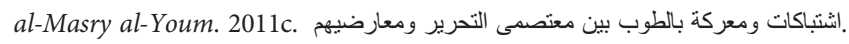
April 12. https://www.almasryalyoum.com/news/details/125055 (accessed September 10, 2018).

al-Masry al-Youm. 2011d. الأحز اب و القوى السياسية تؤيد تعليق مظاهر ات الجمعة لبناء الوطن April 14. https://www.almasryalyoum.com/news/details/125710 (accessed September 10, 2018).

al-Masry al-Youm. 2011e. ستة أبريل نعلق مليونية الجمعة بعد قرار حبس مبارك. April 14. https://www.almasryalyoum.com/news/details/125538 (accessed September 10, 2018).

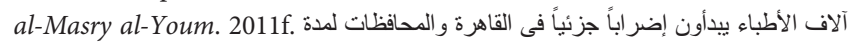

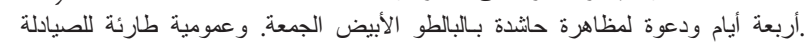
May 18. https://today.almasryalyoum.com/article2.aspx?ArticleID =297201 (accessed 27 March 2019).

al-Masry al-Youm. 2011g. استمرار الفوضى فى غالبية المدارس بالمحافظات لليوم الخامس. September 20. https://www.almasryalyoum.com/news/details/112291 (accessed September 10, 2018).

al-Wafd TV. 2011. Interviews with protesting factory workers. Television broadcast. November 16. https://www.youtube.com/watch?v = JgEhh30KwMI (accessed March 22, 2019).

Amenta, Edwin, Neal Caren, Elizabeth Chiarello, and Yang Su. 2010. "The Political Consequences of Social Movements.” Annual Review of Sociology 36:287-307.

Andrews, Kenneth T., Kraig Beyerlein, and Tuneka Tucker Farnum. 2015. “The Legitimacy of Protest: Explaining White Southerners' Attitudes toward the Civil Rights Movement." Social Forces 94 (3): 1021-44.

Arslanalp, Mert, and Wendy R. Pearlman. 2017. "Mobilization in Military-Controlled Transitions: Lessons from Turkey, Brazil, and Egypt." Comparative Sociology 16 (3): 311-39.

Barrie, Christopher, and Neil Ketchley. 2018. "Opportunity without Organization: Labour Mobilization in Egypt after the January 25 Revolution." Mobilization: An International Quarterly 23 (2): 181-202.

Bayat, Asef. 2010. Life as Politics: How Ordinary People Change the Middle East. Stanford, CA: Stanford University Press.

Bayat, Asef. 2017. Revolution without Revolutionaries: Making Sense of the Arab Spring. Stanford, CA: Stanford University Press.

Beinin, Joel, and Marie Duboc. 2013. "A Workers Social Movement on the Margin of the Global Neoliberal Order, 2004-2012.” In Joel Beinin and Frédéric Vairel, eds., Social Movements, Mobilization, and Contestation in the Middle East and North Africa. 2nd ed. Stanford, CA: Stanford University Press.

Bermeo, Nancy. 1997. "Myths of Moderation: Confrontation and Conflict during Democratic Transitions.” Comparative Politics 29 (3): 305-22.

Bishara, Dina. 2015. "The Politics of Ignoring: Protest Dynamics in Late Mubarak Egypt.” Perspectives on Politics 13 (4): 958-75.

Branton, Regina, Valerie Martinez-Ebers, Tony E. Carey Jr., and Tetsuya Matsubayashi. 2015. "Social Protest and Policy Attitudes: The Case of the 2006 Immigrant Rallies." American Journal of Political Science 59 (2): 390-402.

Bunce, Valerie, and Sharon L. Wolchik. 2011. Defeating Authoritarian Leaders in Postcommunist Countries. Cambridge: Cambridge University Press.

Chalcraft, John. 2014. "Egypt's 25 January Uprising, Hegemonic Contestation, and the Explosion of the Poor." In Fawaz A. Gerges, ed., The New Middle East: Protest and Revolution in the Arab World. Cambridge: Cambridge University Press.

Christian Science Monitor. 2011. "Egyptian Army Empties Tahrir Square." August 1. https://www.csmonitor.com/World/Middle-East/2011/0801/Egyptian -Army-empties-Tahrir-Square (accessed September 10, 2018). 
Clarke, Killian. 2011. "Saying 'Enough': Authoritarianism and Egypt's Kefaya Movement.” Mobilization: An International Quarterly 16 (4): 397-416.

Collier, Ruth. 1999. Paths toward Democracy: The Working Class and Elites in Western Europe and South America. Cambridge: Cambridge University Press.

Doherty, David, and Peter J. Schraeder. 2018. "Social Signals and Participation in the Tunisian Revolution." Journal of Politics 80 (2): 675-91.

Ekiert, Grzegorz, and Jan Kubik. 1999. Rebellious Civil Society: Popular Protest and Democratic Consolidation in Poland, 1989-1993. Ann Arbor: University of Michigan Press.

Evans, Geoffrey, and Stephen Whitefield. 1995. "The Politics and Economics of Democratic Commitment: Support for Democracy in Transition Societies." British Journal of Political Science 25 (4): 485-514.

Gunning, Jeroen, and Ilan Zvi Baron. 2013. Why Occupy a Square? People, Protests and Movements in the Egyptian Revolution. Oxford: Oxford University Press.

Gunsilius, Florian. 2018. "Testability of the Exclusion Restriction in Continuous Instrumental Variable Models.” arXiv, Cornell University. https:// arxiv.org/abs/1806.09517.

Haggard, Stephan, and Robert R. Kaufman. 2016. "Democratization during the Third Wave." Annual Review of Political Science 19:12544.

Hoffman, Michael, and Amaney Jamal. 2014. "Religion in the Arab Spring: Between Two Competing Narratives." Journal of Politics 76 (3): 593 606.

Jamal, Amaney. 2006. "Reassessing Support for Islam and Democracy in the Arab World? Evidence from Egypt and Jordan." World Affairs 169 (2): 51-63.

Jou, Willy. 2016. "Ideological Radicalism and Democratic Experience in New Democracies.” Democratization 23 (4): 592-612.

Kadivar, Mohammad Ali. 2018. "Mass Mobilization and the Durability of New Democracies." American Sociological Review 83 (2): 390-417.

Kadivar, Mohammad Ali, and Neil Ketchley. 2018. "Sticks, Stones, and Molotov Cocktails: Unarmed Collective Violence and Democratization." Socius 4:1-16.

Kandil, Hazem. 2011. "Revolt in Egypt." New Left Review 68:17-55.

Kandil, Hazem. 2013. "Deadlock in Cairo.” London Review of Books 35 (6): $17-20$.

Ketchley, Neil. 2017. Egypt in a Time of Revolution: Contentious Politics and the Arab Spring. Cambridge: Cambridge University Press.

Lindsey, Ursula. 2011. "Revolution and Counterrevolution in the Egyptian Media.” In Jeannie Lynn Sowers and Christopher J. Toensing, eds., The Journey to Tahrir: Revolution, Protest, and Social Change in Egypt. New York: Verso.

Linz, Juan J., and Alfred C. Stepan. 1996. Problems of Democratic Transition and Consolidation: Southern Europe, South America, and PostCommunist Europe. Baltimore: Johns Hopkins University Press.
Makram Ebeid, Dina. 2012. "Manufacturing Stability: Everyday Politics of Work in an Industrial Steel Town in Helwan, Egypt." PhD diss., London School of Economics and Political Science.

Mattes, Robert, and Michael Bratton. 2007. "Learning about Democracy in Africa: Awareness, Performance, and Experience.” American Journal of Political Science 51 (1): 192-217.

Mazaheri, Nimah, and Steve L. Monroe. 2018. "No Arab Bourgeoisie, No Democracy? The Entrepreneurial Middle Class and Democratic Attitudes since the Arab Spring." Comparative Politics 50 (4): 523-50.

Mazumder, Soumyajit. 2018. "The Persistent Effect of U.S. Civil Rights Protests on Political Attitudes." American Journal of Political Science 62 (4): 922-35.

Meirowitz, Adam, and Joshua A. Tucker. 2013. "People Power or a OneShot Deal? A Dynamic Model of Protest." American Journal of Political Science 57 (2): 478-90.

O’Donnell, Guillermo A., and Philippe C. Schmitter. 1986. Transitions from Authoritarian Rule: Tentative Conclusions about Uncertain Transitions. Baltimore: Johns Hopkins University Press.

Przeworski, Adam. 1991. Democracy and the Market: Political and Economic Reforms in Eastern Europe and Latin America. Cambridge: Cambridge University Press.

Sallam, Hesham. 2011. "Striking Back at Egypt's Workers.” Middle East Report 259 (Summer): 20-25.

Shenker, Jack. 2016. The Egyptians: A Radical Story. London: Lane.

Steavenson, Wendell. 2015. Circling the Square: Stories from the Egyptian Revolution. New York: Ecco.

Tertytchnaya, Katerina, and Tomila Lankina. 2020. "Electoral Protests and Political Attitudes under Electoral Authoritarianism." Journal of Politics 82 (1): 285-99.

Tessler, Mark. 2002. "Do Islamic Orientations Influence Attitudes toward Democracy in the Arab World? Evidence from Egypt, Jordan, Morocco, and Algeria." International Journal of Comparative Sociology 43 (3-5): 229-49.

Thompson, Mark R. 2003. Democratic Revolutions: Asia and Eastern Europe. London: Routledge.

Tripp, Charles. 2013. "Performing the Public: Theatres of Power in the Middle East." Constellations 20 (2): 203-16.

Wallace, Sophia J., Chris Zepeda-Millán, and Michael Jones-Correa. 2014. "Spatial and Temporal Proximity: Examining the Effects of Protests on Political Attitudes.” American Journal of Political Science 58 (2): 433-48.

WikiThawra. 2013. حصر فتلي الـ 18 يوم الأولي من الثورة تفصيليا. https://wikithawra .wordpress.com/2013/10/23/25jan18dayscasualities (accessed September 9, 2018).

Younis, Ahmed, and Mohamed Younis. 2011. "Most Egyptians Believe Continued Protests Are Bad for Country.” Gallup, November 28. https:// news.gallup.com/poll/151001/egyptians-believe-continued-protests-bad-country .aspx (accessed March 22, 2019). 